\title{
Carbon dioxide measurement in Swiss-type cheeses by coupling extraction and gas chromatography
}

\author{
F Girard 1, P Boyaval 2 \\ 1 Institut Technique du Gruyère, 73, rue de Saint-Brieuc, BP 6224, 35062 Rennes Cedex; \\ 2 Laboratoire de Recherches de Technologie Laitière, INRA, 65, rue de Saint-Brieuc, \\ 35042 Rennes Cedex, France
}

(Received 24 January 1994; accepted 27 June 1994)

\begin{abstract}
Summary - The microbial production of carbon dioxide $\left(\mathrm{CO}_{2}\right)$ in Swiss-type cheeses is one of the major events during ripening. To better control this formation of eyes, it is necessary to be able to evaluate the $\mathrm{CO}_{2}$ in the body of the cheese. In this paper, we propose a method to liberate the $\mathrm{CO}_{2}$ from the cheese sample dispersed in a citric alkaline solution in a blender and to quantify the liberated gas, by acidification, by the direct coupling between the extraction and a gas chromatography analyser. The proposed method has a linearity between 0 to $10 \mathrm{mmol}^{-1}$ of $\mathrm{CO}_{2}$, a coefficient of variation of $1.20 \%$ and a good repeatability.
\end{abstract}

carbon dioxide / cheese / gas chromatography / analytical method

Résumé - Détermination de la teneur en dioxyde de carbone des fromages de type Suisse par couplage extraction-chromatographie en phase gazeuse. La formation du gaz carbonique $\left(\mathrm{CO}_{2}\right)$ au sein des fromages à pâte pressée cuite est l'un des événements majeurs observables au cours de l'affinage. Le strict contrôle de la formation des yeux nécessite une méthode fiable de mesure du $\mathrm{CO}_{2}$ dissous dans la pâte. Dans cet article, nous décrivons une méthode qui permet d'extraire le $\mathrm{CO}_{2}$ d'échantillons de fromage broyés dans une solution citrique alcaline et d'en mesurer la quantité à l'aide d'un chromatographe en phase gazeuse après acidification de la solution. La méthode proposée présente une parfaite linéarité de réponse entre 0 et $10 \mathrm{mmol}^{-1}$ de $\mathrm{CO}_{2}$, un coefficient de variation de $1,20 \%$ et une bonne répétabilité. De plus, elle est simple à mettre en œuvre.

dioxyde de carbone / fromage / chromatographie en phase gazeuse / méthode d'analyse 


\section{INTRODUCTION}

In France, the production of Emmental cheese has reached 212000 tons in 1993 (CNIEL, 1994). This hard cooked cheese is the first French cheese and the second, on a world-wide scale, after Cheddar. In this kind of Swiss-type cheese, production of carbon dioxide $\left(\mathrm{CO}_{2}\right)$, due to lactate breakdown by propionibacteria (Steffen et al, 1987), plays one of the major roles during the ripening process by allowing eyes formation. In the cheese loaf, the amount of $\mathrm{CO}_{2}$ is scattered as follows: $48 \%$ dissolved in the body, $20 \%$ in the eyes and $32 \%$ diffused through the rind (Steffen et al, 1987). In order to optimise the maturation process and so the quality of cheese, it is necessary to measure the $\mathrm{CO}_{2}$ dissolved in the body all along the cheese processing.

In the literature, most of the data concerning $\mathrm{CO}_{2}$ produced by propionibacteria in a culture media or related to the bacterial metabolism in cheese, are calculated from the final products or intermediate compound concentrations and from one or several equations reflecting roughly the carbon metabolism (Hettinga and Reinbold, 1972). Even using the work done by Wood (1981) on propionibacteria, these sketchy data do not permit to construct an accurate carbon balance. Moreover, none was carried out using lactate as a substrate. $\mathrm{CO}_{2}$ measurements are always failing to reach the $100 \%$ carbon recovery.

The first attempt to measure $\mathrm{CO}_{2}$ generated by micro-organisms was performed by Leichman (1896). Then, different wellknown authors, generally working on lactic acid bacteria (Freudenreich and OrlaJensen, 1906; Orla-Jensen, 1919; Allen, 1939), developed special apparatuses, but none of them appeared reliable.

In 1945, Gibson and Abdel-Malek measured $\mathrm{CO}_{2}$ production by incubating cultures in a volumetric flask with a calibrated neck. This method was used to differentiate heterofermentative lactic acid bacteria, organisms producing a detectable quantity of gas, from other lactic acid bacteria or sporeforming bacilli. They demonstrated that the amount of $\mathrm{CO}_{2}$ formed during fermentation of sugars depends on several factors such as sugar (nature and concentration) and buffering capacity of the medium. Therefore, this method was not quantitative. Gravimetric, manometric and titrimetric methods were used until 1978 (Sandine et al, 1957; Robertson, 1957, 1962; Hoglund et al, 1972; Flückiger et al, 1978). More recently, Bosset et al (1986) measured the partial pressure of $\mathrm{CO}_{2}$ in various liquid fermented milk products using a gas-sensitive $\mathrm{CO}_{2}$ electrode. In a review article, Dixon and Kell (1989) described more than fifteen methods used in estimation of determination of $\mathrm{CO}_{2}$ during fermentations, in the liquid or gas phase. In 1992, a simple method based on the chemical reaction of $\mathrm{CO}_{2}$ with a specific indicator layer packed into gas diffusion tubes was described by Kneifel and Gretner. Mohr et al (1993) adapted the method of King and Mabbitt (1982) who used gas chromatography to measure $\mathrm{CO}_{2}$ that was added to milk in order to preserve it, by lowering the $\mathrm{pH}$. Gas chromatographic methods were previously developed (Kreula and Moisio, 1970; Ross, 1987) but required a sample preparation of 17 to $24 \mathrm{~h}$, neglected the solubility of $\mathrm{CO}_{2}$ in aqueous solutions and did not account for the difference of pressure among the bottles.

Data on the level of $\mathrm{CO}_{2}$ dissolved in the body of hard-cooked cheese, important during ripening, are not available in the factories, probably because of the difficulties encountered to measure it. Therefore, attempts were made to develop methods in the beginning of the century (Clark, 1917). Hoestettler (1944) estimated the $\mathrm{CO}_{2}$ in Emmental cheese by drawing the gas off under vacuum. Hiscox et al (1941) estimated the dissolved $\mathrm{CO}_{2}$ of Cheddar cheese in 
connexion with the estimation of volatile acids by subtraction of values obtained with aerated samples from the values obtained with non-aerated samples. In 1953, Swartling and Willart, working on Herrgärt cheese, developed a titrimetric method. The sample was emulsified in alkali, acidified and $\mathrm{CO}_{2}$ was carried away in $\mathrm{CO}_{2}$-free air from which it was absorbed in a standard solution of barium hydroxide. The excess of barium hydroxide was measured using titrated acid. Robertson $(1957,1962)$ adapted the previous method to measure the $\mathrm{CO}_{2}$ content of New-Zealand Cheddar cheese. Later on, in the eighties, a Swiss team (Bosset et al, 1980 ) carried on with a new method to determine $\mathrm{CO}_{2}$ in food products with particular application to cheese. Samples were emulsified, under reduced pressure, in an alkaline citrate medium using a mixer. Carbon dioxide was quantitatively displaced into the headspace by addition of an excess of sulphuric acid. Measurements were carried out with a specific non-dispersive infrared detector. Afterwards, Bosset et al (1989) described an analyser based on gas chromatographic separation with thermal conductivity detection which can be used for the analysis of gas atmosphere over dairy products such as canned milk powder, canned condensed milk, cheese packed in cans or with plastic film and yogurt. An enzymic procedure was used for determining $\mathrm{CO}_{2}$ in blood serum (Forrester et al, 1976). The procedure was adapted by Crow and Martley (1991) for the measurement of $\mathrm{CO}_{2}$ dissolved in Cheddar cheese. But none of these methods can be routinely used. Titrimetric methods are not accurate $(10 \%)$. Enzymic techniques are much more accurate $(0.4 \%)$ however, such a kind of cheese as Emmental shows marked variations of $\mathrm{CO}_{2}$ concentration within the loaf of cheese so the sample $(5 \mathrm{~g})$ becomes absolutely not representative. Methods using infrared detector require, like titrimetric methods, the release and measurement of the total amount of $\mathrm{CO}_{2}$ (accuracy: $2 \%$ ). The vapor must be maintained constant because of its interference with the measurements.

The aim of the present investigation was to determine $\mathrm{CO}_{2}$ dissolved in Swiss-type cheese. The method was chosen, taking into account the different methods already studied. $\mathrm{CO}_{2}$ was estimated using a gas/solid chromatography analyser equipped with a thermal conductivity detector, after treatment of the sample according to the method of Bosset et al $(1979,1980)$.

\section{MATERIALS AND METHODS}

\section{Analytical system}

The analytic system is illustrated in figure 1. The sample was introduced in a modified stainless steel gas proof 1-1 blender (Waring S 1021 , Standa Industrie, Caen, France) equipped with a two-speed motor. The cover was modified by welding five connexions $(5 \mathrm{~cm}$ long and a $5 \mathrm{~mm}$ diameter). The first one was equipped with a Bourdon depression-meter ( 0 to -760 mbar, Hartereau, Rennes, France), The second one was connected to the controlled vacuum system. The third one was connected to the reference gas $\left(\mathrm{CO}_{2} 1 \% \pm 0.02, \mathrm{v} / \mathrm{v}\right.$, in nitrogen, Aga, France). The fourth one was connected to the gas chromatograph and the last one was equipped with a teflon funnel. $\mathrm{CO}_{2}$ was analyzed in a Varian gas chromatograph (3400, equipped with a $250 \mu$ ) automatic injection loop, Les Ulis, France). Separation took place in a packed column $(3.66 \mathrm{~m} \times 3.2$ $\mathrm{mm}$; Haye Sep, $\mathrm{N}, 80 / 100 \mathrm{Mesh})$ at $105^{\circ} \mathrm{C}$ with highly pure hydrogen as gas vector (N55, Alphagaz, France, flow rate $50 \mathrm{ml}^{-1}$, pressure $2.8 \mathrm{X}$ $10^{5} \mathrm{~Pa}$. A thermal conductivity detector was used at $140^{\circ} \mathrm{C}$. The results were analyzed and stored in a microcomputer equipped with the software Gold (Beckman, USA). Each analysis took 4.5 $\mathrm{min}$. Between each sample, $10 \mathrm{~min}$ were required in order to clean the column (at $140^{\circ} \mathrm{C}$ ).

\section{Sampling and sample preparation}

Each piece of cheese was a $3 \mathrm{~kg}$ parallelepipedic block of $9 \mathrm{~cm}$ width, with both rinds, taken in the 


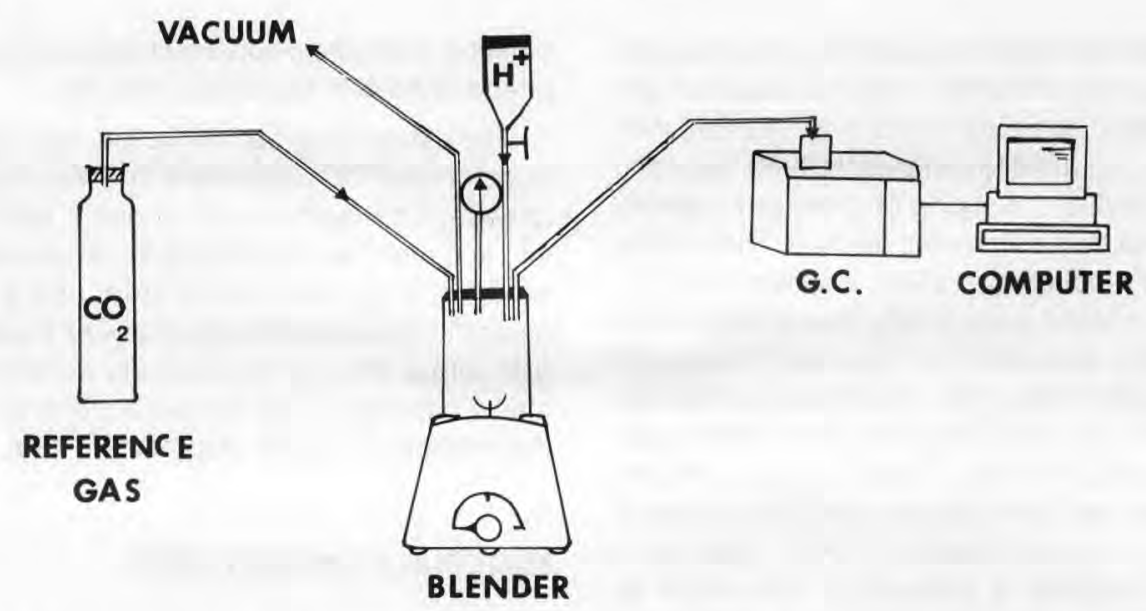

Fig 1. Equipment used for the determination of $\mathrm{CO}_{2}$ in cheese.

Équipement mis en œuvre pour la mesure du $\mathrm{CO}_{2}$ dans les fromages.

central part of the loaf, kept in a sealed bag, under low pressure, at $+4^{\circ} \mathrm{C}$. Six to eight samples from 30 to $50 \mathrm{~g}$ were collected in each block with a cheese borer ( $1.8 \times 18 \mathrm{~cm}$, in stainless steel).

The sample was then immersed and finely dispersed during storage in $60 \mathrm{~g}$ of a citric alkaline solution (weighted exactly) (sodium hydroxide in pellets, $10 \mathrm{~g} \mathrm{H}^{-1}$ (Merck, pro analysi, Darmstadt, Germany) and tri-sodium citrate, $50 \mathrm{~g} \mathrm{I}^{-1}$ (Merck, Germany), dissolved in a freshly distilled, sterilized water, cooled under low pressure to avoid air redissolution) and stored in gas-proof vials. Just before analysis, water was added to the sample in order to supplement the cheese weight to $100 \mathrm{~g}$ (to avoid variations of volume in the blender; Bosset et al, 1980).

\section{Analysis}

The sample was then placed in the blender, which was subsequently connected to vacuum $(-450 \pm$ $50 \mathrm{mbar}$ ). The blender was then isolated; the grinding was performed under partial vacuum for $2 \mathrm{~min}$. After $1.5 \mathrm{~min}, 50 \mathrm{ml}$ of sulfuric acid $\left(2.5 \mathrm{~mol}^{-1}\right.$, Merck, Darmstad, Germany) was added from the teflon funnel. The blender was gently turned back to atmospheric pressure then isolated before several automatic injections were finally carried out.

The four first ones were used to drain the 1.0 $\mathrm{ml}$ volume of the tubing between the blender and the injection loop and discarded. The four next ones were then collected and the value was the arithmetic mean of these four injections.

The result was then calculated from the following equation:

$\% \mathrm{CO}_{2} \times$ (vol (blender)-vol

(cheese solution)) $\times 1000$

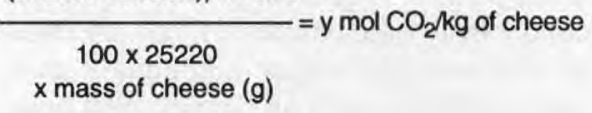

with vol $=$ volume

$\mathrm{R}=25.22 \mathrm{ml} \mathrm{CO} / \mathrm{mmol} \mathrm{CO}_{2}$ at $20^{\circ} \mathrm{C}$ and under $720 \mathrm{mbar}$.

\section{Calibration of the analytic system}

This procedure was done weekly. The stability of this calibration along this period has been verified. In order to discard completely the air of the blender, vacuum was firstly applied (-700 mbar) and then highly pure $\mathrm{CO}_{2}(1 \%, \mathrm{v} / \mathrm{v})$ was added in it, until atmospheric pressure was restored. This step was repeated three times. Afterwards, a continuous $\mathrm{CO}_{2}$ flow rate was allowed to sweep the blender to be sure to maintain $\mathrm{CO}_{2}$ at the atmospheric pressure (otherwise, an overpression can alter the quality of the calibration) and that the multiple injections did not create any 
depression also detrimental for the analysis. Nine injections were then carried out in which the five last were taken into account to calibrate the apparatus. Six calibrations were performed (standard deviations: 0.025 for $\mathrm{CO}_{2}$ at $1 \%$ ).

\section{Linearity of the method}

In order to evaluate the linearity of the method, solutions of sodium carbonate $114 \mathrm{mmol}^{-1}$ and $228 \mathrm{mmol}^{-1}$ (Merck, Darmstadt, Germany) were used to liberate $\mathrm{CO}_{2}$ in the blender by addition of sulphuric acid (same procedure as for samples):

$$
\mathrm{Na}_{2} \mathrm{CO}_{3}+\mathrm{H}_{2} \mathrm{SO}_{4} \rightarrow \mathrm{H}_{2} \mathrm{O}+\mathrm{CO}_{2}{ }^{\star}+\mathrm{Na}_{2} \mathrm{SO}_{4}
$$

\section{RESULTS}

\section{Limit of detection}

The limit of detection was calculated at 6.3 $10^{-3} \mathrm{mmol} \mathrm{I}^{-1}$ of $\mathrm{CO}_{2}(0.016 \%)$ on the base of a signal-to-noise ratio of 3 (from a chromatogram of $\mathrm{CO}_{2}$ at $1 \%$ in nitrogen). The $\mathrm{CO}_{2}$ content of the air of the laboratory was measured. A set of values of $0.040 \% \pm$ 0.010 was easily detected. This value is in close agreement with the value of $0.031 \% \pm$ 0.005 of the literature (Kuiperg, 1976). It was not possible to test lower concentrations as calibrated gas was not available below this limit. Lower gas concentration could be prepared by dilution of the reference gas. But, as already demonstrated by Bosset et al (1989), the biggest error will be in the preparation of the diluted gas rather than in the measurement itself.

\section{Linearity of the method}

Figure 2 illustrates the response of the complete device to the liberation of $\mathrm{CO}_{2}$ from sodium carbonate. The regression line can be described by the equation:

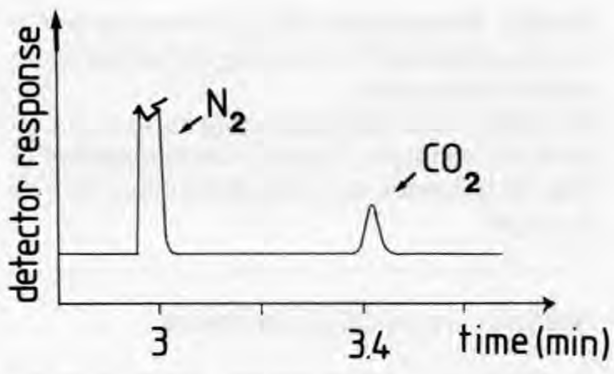

Fig 2. Example of a chromatogram obtained by this method.

Exemple de chromatogramme obtenu à l'aide de cette méthode.

$$
\text { peak area }=0.64 \times \mathrm{mmol} \mathrm{CO}_{2}+0.12
$$

(with $r=0.998$ )

which is usable for the conversion of peak area in content of carbon dioxide in the sample (before data reduction to $1 \mathrm{~kg}$ sample weight). The method has a good linearity between 0 to $10 \mathrm{mmol} \mathrm{I}^{-1}$ of $\mathrm{CO}_{2}$.

\section{Repeatability of the method}

In order to analyse this characteristic, $330 \pm$ $20 \mathrm{~g}$ of a cheese block were prepared in the citric alkaline solution kept in a gas-tight glass bottle. Six series of analysis were performed with this preparation. The results are presented in table $\mathrm{I}$. The mean value is $24.1 \mathrm{mmol}$ of $\mathrm{CO}_{2}$ for $1 \mathrm{~kg}$ of cheese. The coefficient of variation (CV) is $1.2 \%$.

The application of such a method to the determination of the carbon dioxide content of cheese samples needs a blank which must be prepared and measured before each cheese sample (especially if the value of this blank and of the sample are timedependent as is the case in this type of measurement). Moreover, the stability of the gas content of the sample between sampling and measurement must be ensured in order to present an interest for the professionals. 
Table I. Repeatability of $\mathrm{CO}_{2}$ measurement in cheese. Example for six analyses of the same cheese preparation.

Évaluation de la répétabilité de la mesure de $\mathrm{CO}_{2}$ dans les fromages. Exemple de la répétition (6 fois) de la mesure sur une même préparation de fromage.

Analysis $\mathrm{mmol} \mathrm{CO}_{2} / \mathrm{kg}$ of cheese

\begin{tabular}{lll}
\hline 1 & 24.5 & mean $(X)=24.1$ \\
2 & 23.8 & $\mathrm{SD}=2.9$ \\
3 & 24.2 & $\mathrm{CV}=1.20 \%$ \\
4 & 23.6 & \\
5 & 24.2 & \\
6 & 24.1 & \\
\hline
\end{tabular}

The blank contains all the constituents except the cheese. The value of this blank has been systematically subtracted from the value determined with the sample.

\section{Importance of the gas tightness of the bottles used for the storage}

When the plastic sampling bottles were used to keep the citric alkaline solution alone, the results were systematically higher than for the samples kept in glass bottles, leading to errors from 2 to $15 \%$ (table II). Cheese solutions kept in plastic bottles were not stable in term of $\mathrm{CO}_{2}$ content. These increasing values are mainly due to the carbonatation of

Table II. Influence of storage time and storage conditions (vials) between the immersion in the citric alkaline solution and analysis.

Influence du temps de conservation et des conditions de conservation de l'échantillon dans la solution citrique alcaline avant analyse.

\begin{tabular}{|c|c|c|c|c|c|c|c|}
\hline \multirow{3}{*}{$\begin{array}{l}\text { Day of } \\
\text { storage }\end{array}$} & \multicolumn{7}{|c|}{$\mathrm{mmol}$ of $\mathrm{CO}_{2} / \mathrm{kg}$ of cheese } \\
\hline & \multicolumn{4}{|c|}{ Glass bottle } & \multicolumn{3}{|c|}{ Plastic bottle } \\
\hline & Sample 1 & Sample 2 & Blank & $\Delta$ & Sample 3 & Blank & $\Delta$ \\
\hline 0 & $\begin{array}{l}18.0 \\
17.1\end{array}$ & 20.4 & 1.6 & $\begin{array}{c}16.4 ; 18.8 \\
15.5\end{array}$ & $\begin{array}{l}21.5 \\
21.6\end{array}$ & $\begin{array}{c}1.6 \\
t+6 h=2.0\end{array}$ & $\begin{array}{l}19.9 \\
20.0\end{array}$ \\
\hline 1 & ND & 20.5 & 1.6 & 18.9 & ND & ND & \\
\hline 2 & $\begin{array}{l}18.0 \\
1.78\end{array}$ & ND & 1.9 & $\begin{array}{l}16.1 \\
15.9\end{array}$ & $\begin{array}{l}22.3 \\
24.4\end{array}$ & 2.3 & $\begin{array}{l}20.0 \\
22.1\end{array}$ \\
\hline 3 & ND & $\begin{array}{l}20.5 \\
20.9\end{array}$ & 1.8 & $\begin{array}{l}18.7 \\
19.1\end{array}$ & ND & ND & \\
\hline 4 & $\begin{array}{l}17.9 \\
17.7\end{array}$ & ND & 1.7 & $\begin{array}{l}16.2 \\
16.0\end{array}$ & $\begin{array}{l}23.1 \\
23.1\end{array}$ & 2.0 & 21.1 \\
\hline 7 & 17.9 & 21.0 & 1.6 & $\begin{array}{l}16.3 \\
19.4\end{array}$ & $\begin{array}{l}2.28 \\
2.47\end{array}$ & 2.8 & $\begin{array}{l}20.0 \\
21.9\end{array}$ \\
\hline
\end{tabular}

ND: not determined. Blank = citric alkaline solution without cheese. $\Delta=$ sample value - blank value. Some trials have been performed twice (two values).

ND : non déterminé. Blank = solution citrique alcaline sans échantillon de fromage. $\Delta=$ valeur de l'échantillon après soustraction du témoin. Certains échantillons ont fait l'objet de 2 séries de dosages conduisant à 2 valeurs. 
the citric alkaline solution through the container: 0.16 to $0.28 \mathrm{mmol}^{-1} \mathrm{CO}_{2}$ in 7 days of storage (table II). On the opposite, when the samples were kept in glass bottles, we observed no difference in $\mathrm{CO}_{2}$ measurements during 7 days of storage (table II).

\section{Sampling}

The losses of $\mathrm{CO}_{2}$ between the cheese samples extracted from the loaf are fast and considerable due to the acidic medium of cheese body $\left(\mathrm{H}_{2} \mathrm{CO}_{3} \rightarrow \mathrm{H}_{2} \mathrm{O}+\mathrm{CO}_{2}\right)$ and to the difference of partial pressure of $\mathrm{CO}_{2}$ between cheese body and ambient air. They lead to a substantial decrease of the $\mathrm{CO}_{2}$ value. In order to show this phenomenon, several cheese bores were not immediately immersed in the citric alkaline solution but let in the laboratory atmosphere $12 \mathrm{~h}$ before dispersion/dissolution treatment. The normally treated samples (of the same cheese block) presented $31.0 \mathrm{mmol} \mathrm{CO} / \mathrm{kg}$ of cheese (CV: $3.0 \%$ ) while the other one presented only $8.7 \mathrm{mmol} \mathrm{CO} / \mathrm{kg}$ of cheese.

This CV of $3.7 \%$ is high in comparison with the CV of $1.2 \%$ of the method. It is probably due to the difference of the surface exchange cheese-air between the different samples (eyes number, size and heterogeneity of the samples).

\section{Heterogeneity of the $\mathrm{CO}_{2}$ content of the cheese}

The heterogeneity of the $\mathrm{CO}_{2}$ content within a cheese block is evidenced in table III. The CV varied from 0.9 to $8.1 \%$, value higher than the $1.2 \%$ of the repeated analysis of the same cheese preparation (table I). These variations in the measurement of the $\mathrm{CO}_{2}$ content are due much more to sample heterogeneity than to the repeatability of the method.
Table III. Heterogeneity of the $\mathrm{CO}_{2}$ content of the cheese body.

Hétérogénéité du $\mathrm{CO}_{2}$ dissous dans la pâte.

\begin{tabular}{lcccc}
\hline Samples & $\begin{array}{c}X \text { mmol/kg } \\
\text { of cheese }\end{array}$ & SD & $C V(\%)$ & $\mathrm{n}$ \\
\hline A & 23.3 & 1.2 & 5.1 & 6 \\
B & 22.6 & 1.8 & 7.9 & 5 \\
C & 24.9 & 0.9 & 3.6 & 6 \\
D & 23.3 & 1.9 & 8.1 & 5 \\
E & 25.0 & 0.9 & 3.6 & 6 \\
F & 31.0 & 0.3 & 0.9 & 3 \\
\hline
\end{tabular}

Each value is the average of $3-6$ measurements for the same piece of cheese. The samples were taken from different cheeses (A-F).

Chaque échantillon est caractérisé par sa moyenne $X$, son écart type (SD) et son coefficient de variation (CV) calculé sur la base de 3,5 ou 6 mesures (n) effectuées sur la même meule de fromage. Les échantillons $A$ à $F$ proviennent de meules différentes de la même sorte de fromage (Swiss-type).

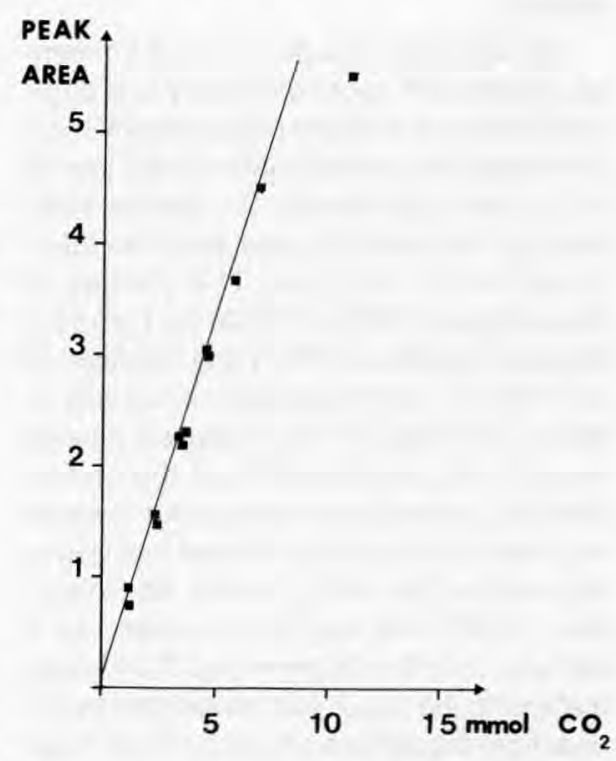

Fig 3. A standard curve of gas chromatographic peak areas of $\mathrm{CO}_{2}$ derived from solutions of sodium bicarbonate of different molarities.

Un exemple des courbes d'étalonnage obtenues avec des solutions de bicarbonate de différentes molarités. 


\section{DISCUSSION}

The proposed method can be compared with the others already published in the literature for $\mathrm{CO}_{2}$ measurements in cheese. This method used a detector which has been proven to present an excellent linear response from 0 to $10 \mathrm{mmoll}^{-1}$ of $\mathrm{CO}_{2}$ with a high sensitivity and a detection limit of 6.3 $10^{-3} \mathrm{mmol} \mathrm{I}^{-1}$. Bosset et al (1980) presented a CV of $1.66 \%$ (here $1.2 \% ; n=6$ ) with a standard deviation of $0.0934(n=10)$ (here 0.029 which is comparable to the value $0.033(n=3)$ obtained by Hoglund et al, 1972). The standard deviation of the enzymatic method was $1 \mathrm{mmol} / \mathrm{kg}$ of cheese (mean value: $11 \mathrm{mmol} / \mathrm{kg} ; n=6$ ) for estimation of $\mathrm{CO}_{2}$ in Cheddar cheese (Crow and Martley, 1991). The gas chromatographic technique developed by Ross (1987) had a CV of $8.0 \%(n=3)$ for within-day variation.

The sampling from 30 to $50 \mathrm{~g}$ of Emmental cheese with a cheese borer is a common practice in industry and is already used to evaluate the eyes formation in the loaves and to taste the cheese. So, cheese sampling by this method could easily be introduced in the factories. The studies of Swartling and Willart (1953) for Herrgärd cheese, Robertson (1957) and Flückiger et al (1978) for Swiss-type cheeses as well as Blanc et al (1980) for Swiss Gruyère cheese have clearly established that the carbon dioxide concentration decreased towards the outer surface of the cheese loaf due to its pk value (pka of $\mathrm{CO}_{2}=4.6$ ). So Robertson (1957) had decided to take, as a sample, only the deepest end of the plug, discarding the upper part considered as too near from the surface and so having a lower $\mathrm{CO}_{2}$ content than the inner part of the cheese. This concentration gradient of carbon dioxide is not the only reason of the heterogeneity of the sample. The cheese borer does not allow to take sample with 'complete eye'. Most of the eyes are cut through, so their particular gas content is immediately lost into the laboratory atmosphere. The cheese body surrounding the eyes has probably a slightly different $\mathrm{CO}_{2}$ content than the rest of the body. So, the density of the eyes in the bore is probably of importance in the $\mathrm{CO}_{2}$ measurement.

Based on the results of Bosset et al (1980) and our own results, we proposed to immediately immerse and weigh this sample, in a citric alkaline solution prepared in a gas proof glass bottle. This bottle can be stored and subsequently analysed or mailed to the central laboratory for measurement without any problem for several weeks.

This effect of carbonatation of sodium hydroxide is well known but its importance is particularly evidenced when low levels of $\mathrm{CO}_{2}$ must be measured as is the case in our method. Moreover, the preparation of this alkaline solution must be done with freshly distilled water and well protected caustic tablets. In a proper gas proof glass container, this solution can be kept 2 weeks. The only possibility to take into account this interference effect is to determine and subtract the corresponding blank. This method allows the investigation of carbon dioxide formation in hard and semi-hard cheeses like Emmental, but also for cheeses with lower eyes formation (Comté, Gouda, Mimolette). This information is of great interest to follow the propionic acid fermentation in such cheeses.

This method presents some limitations: only four samples can be measured per hour and the analysis must be performed by well-trained technicians. In order to increase the quality of the measurements day-to-day temperature and atmospheric pressure variations should be taken into account.

The elaboration of a robust method to follow $\mathrm{CO}_{2}$ formation in cheese body opens wide fields of research: i) investigations on the propionic acid formation during cheese 
manufacturing and especially during ripening, leading to a better control of this crucial period; ii) comparisons of potential formation of $\mathrm{CO}_{2}$ by different strains of propionic starters in true cheese environment; and iii) examination of the $\mathrm{CO}_{2}$ content of the cheese body after cutting of the loaf and before wrapping, to better control the $\mathrm{CO}_{2}$ content of the gas added in the packaging.

This point would allow to subsequently diminish the bringing back of cheese parts to the factories, mainly due to problems of appearance of wrapped cheese (blowing by $\mathrm{CO}_{2}$ release in the plastic bag or sticking of the plastic film on the cheese portion, leading to a wet appearance). This point was recently examined in Canada by Fedio et al (1994).

\section{ACKNOWLEDGMENTS}

The authors gratefully acknowledge JY Meudec (ITG) and A Fauvel (Entremont) for the cheese sampling facilities, C Corre and C Dupuis for their help during the experiments and JL Maubois and JR Kerjean for the excellent facilities extended to us to realize this work.

\section{REFERENCES}

Allen LA (1939) Methods of measuring gas production. J Dairy Res 10, 1-6

Blanc B, Bosset JO, Pauchard JP (1980) Étude de la teneur et du dégagement en gaz carbonique du fromage de Gruyère en cours de maturation. Schweiz Milchwirtsch Forsch 9, 9-14

Bosset JO, Pauchard JP, Flückiger E, Knecht I, Knecht $P$ (1979) Umbau eines Küchenmixers für die Dampfrauanalyse von flüchtigen oder gasfömigen Komponenten in Nahrungsmittel. GIT Fachzeitschrift für das Laboratorium 23, 920-921

Bosset JO, Pauchard JP, Flückiger E, Blanc B (1980) Nouvelle méthode de dosage du $\mathrm{CO}_{2}$ dans les produits alimentaires et application au fromage. Anal Chim Acta 115, 315-321

Bosset JO, Pauchard JP, Gauch R (1986) Application d'une électrode sensible à la pression partielle du dioxyde de carbone au dosage in situ de ce com- posant dans quelques produits laitiers fermentés. Lait 66, 353-370

Bosset JO, Collomb M, Spahni-Rey M, Gauch R (1989) L'analyse des gaz entourant les aliments préemballés ; revue des méthodes actuelles et mise au point d'un nouveau chromatographe gaz/solide à détection catharométrique. Trav Chim Aliment Hyg 80, 430-451

Clark WM (1917) On the formation of eyes in Emmental cheese. J Dairy Sci 1, 91-113

CNIEL (1994) L'économie laitière en chiffres. CNIEL, Paris

Crow VL, Martley FG (1991) An enzymic assay for $\mathrm{CO}_{2}$ in cheese. J Dairy Res 58, 521-525

Dixon NM, Kell DB (1989) The control and measurement of $\mathrm{CO}_{2}$ during fermentations. $J$ Microbiol Methods 10, 155-176

Fedio WM, Ozimek L, Wolfe FH (1994) Gas production during the storage of Swiss cheese. Milchwissenschaft 49, 3-8

Flückiger E, Montagne DH, Steffen C (1978) Beitrag zur Kenntnis der $\mathrm{CO}_{2}$-bildung im Emmentalerkăse vor Beginn der Propiosăuregärung. Schweiz Milchwirtsch Forsch 7, 73-78

Forrester RL, Wataji LJ, Silverman DA, Pierre KJ (1976) Enzymatic method for determination of $\mathrm{CO}_{2}$ in serum. Clin Chem 22, 243-245

Freudenreich E von, Orla-Jensen S (1906) Uber die in Emmentalerkäse stattfindeme Propiosäure-garüng. Zentralbl Bakteriol Parasitenkd Infektionskr Hyg Abt 2, 529-546

Gibson T, Abdel-Malek Y (1945) The formation of carbon dioxide by lactic acid bacteria and Bacillus licheniformis and a cultural method of detecting the process. J Dairy Sci 14, 35-44

Hettinga DH, Reinbold GW (1972) The propionic-acid bacteria. A review. II. Metabolism. J Milk Food Technol 35, 358-372

Hiscox ER, Harrison J, Wolf JZ (1941) Volatile acids of cheese. III. Application of the extraction method. $\checkmark$ Dairy Res 12, 155-169

Hoestettler H (1944) Die garungschemischen Vorgănge im Hartkäse. Thesis, Bern

Hoglund GF, Fryer TF, Gilles J (1972) The influence of starter, cheddaring and pressing on cheddar cheese texture. N Z J Dairy Sci Technol 7, 150-154

King JJ, Mabbitt LA (1982) Preservation of raw milk by addition of $\mathrm{CO}_{2}$. J Dairy Res 49, 439-447

Kneifel W, Gretner I (1992) A simple method for estimating the carbon dioxide production of mesophilic starter cultures. Milchwissenschaft 47, 708-711

Kreula M, Moisio T (1970) Chromatographic method for the estimation of gases dissolved in liquid. Suomen Kemistil 43, 51-53

Kuiperg P (1976) In: the Merk Index, 9th edition, Merck and $\mathrm{Co}$, Inc Rahway, NJ USA 1815, p 230 
Leichman G (1896) Uber die freiwillige Säuerung der Milch. Zentralbl Bakteriol Parasitenkd Infektionskr Hyg Abt 2, 777-780

Mohr SA, Zottola EA, Reineccius GA (1993) The use of gas chromatography to measure carbon dioxide production by dairy starter cultures. J Dairy Sci 76, 33503353

Orla-Jensen S (1919) The Lactic Acid Bacteria. Thesis, Copenhagen

Robertson PS (1957) The carbon dioxide content of New-Zealand Cheddar cheese. J Dairy Res 24, 235241

Robertson PS (1962) The estimation of carbon dioxide in Cheddar cheese. J Dairy Res 29, 321-323

Ross LF (1987) Gas chromatographic technique to simultaneously quantitate the gases produced by intesti- nal microorganisms from fermentation mixtures. J Chromatogr 414, 405-410

Sandine WE, Elliker PR, Anderson AW (1957) A simple apparatus for measurements of gas production and activity of lactic starter cultures. Milk Prod J 48, 12 $13 ; 39-40$

Steffen C, Flüeckiger E, Bosset JO, Ruegg M (1987) Swiss-type varieties. In: Cheese: chemistry, physics and microbiology, Vol 2 (Fox PF, ed) Elsevier, London, 93-120

Swartling P, Willart S (1953) Estimation of bound and dissolved carbon dioxide in cheese. Proc 13th Int Dairy Congr I, 419-420

Wood HG (1981) Metabolic cycles in the fermentation by propionic acid bacteria. Curr Top Cell Regul 18, 255287 